A Journal for Language Learning Tydskrif vir Taalaanleer

\title{
EXPLORING GRADUATE STUDENT TEACHERS' PERCEPTIONS OF THEIR PRAXIS AFTER AN AELS COURSE
}

\author{
Laura Arnold \\ University of Johannesburg
}

While speakers of English as an additional language are more common than native English speakers, most English teachers do not know how to teach plurilingual learners in their classrooms. Though studies have looked at the effect of teacher education on praxis, there is a dearth of studies in South Africa that have examined teachers' perceptions of their praxis after a course on bilingual education models and practices. This study investigates whether in-service teachers feel that the 'Paradigms and Methods in Applied English Language Studies' course helped them to further develop their praxis. Students' weekly reflection pieces were examined for evidence of critical reflection before interviews were conducted with three students who have taught, or are currently teaching in under-resourced areas. All participants reported that they had developed a more bilingual teaching praxis, but they often felt unsure of how to practically implement their learning from the course. Based on this finding two recommendations to lecturers and course coordinators of AELS courses are provided. Teacher praxis could be strengthened by 1) referring students to articles on bilingual education models and practices that mirror their teaching contexts and 2) explicitly teaching students how to reflect on implementing the theories that they have learned during the course within their classrooms.

\section{Keywords}

Praxis, teacher education, reflection, translanguaging, Black South African English (BSAE), code-switching

\section{INTRODUCTION}

South Africa is a multilingual society where the majority of the plurilingual population learns to speak more than two languages, often at an early age. However, most children have little exposure to English in the home context. In South Africa primary school learners are taught through their mother tongue for the first three years before English becomes the medium of instruction. Support for other bilingual education systems exists, but resistance within South Africa to these systems remains strong. Much of this resistance stems from Apartheid where children of colour experienced sub-standard mother tongue education, particularly where English as a subject was concerned (Heugh, 2015). Parents and teachers also mistakenly believe that implementing 'English only education policies' will help learners learn the target language. Ironically these policies are particularly popular in contexts where learners have little exposure to English outside the classroom and may need to use their knowledge of other languages to supplement their learning of the target language (Sayed \& Soudien, 2005). This situation means that while schools have the right to choose the medium of instruction according to the Schools Act, the de facto standard is mother tongue education for the first 
three years of schooling and English as the language of teaching and learning from the fourth grade onwards (Sayed \& Soudien, 2005).

In order to challenge the resistance to bilingual education models and multilingual practices, South African teachers require more knowledge about how these alternative models and practices can be used within the classroom, and what benefits their learners would receive from this new approach. Eleven current or former teachers of English as a subject received this opportunity when they enrolled in the Paradigms and Methods in Applied English Language Studies (AELS) elective as part of their Honours or Master's degree at a South African university. Each week students were given articles to read by the course coordinator, who was also the AELS lecturer. Students were expected to participate in class discussions around the readings, and hand in a written reflection piece during the weekly tutorial. The ungraded, written reflection pieces were set as a course requirement.

One of the aims of this course was to engage these students in a discussion around how English language teaching was undergoing a paradigm shift where the needs of the majority, the bilingual and plurilingual learners, needed to be met through the increasing provision of bilingual education models and multilingual practices. Towards the beginning of the course students were informed that prior to the mid-twentieth century most education systems used one language of teaching and learning, and that this model was supported by research which seemed to indicate that monolingual children were cognitively superior to their bilingual counterparts (Akbulut, 2007, García, 2009). Flaws with this research, such as the comparison of lower-socioeconomic, mainly migrant bilingual children, to those from the middle classes, were exposed (Akbulut, 2007). This research also explained some of the cognitive benefits that bilingual children experience (Akbulut, 2007; Bialystok \& Barac, 2012).

Two different models of bilingual education were then presented. The first, subtractive bilingual education, occurs when the learners initially learn in their mother tongue before the target language is introduced (García \& Wei, 2014). The second, additive bilingual education, occurs when learners are taught in their mother tongue in conjunction with English as a subject for six to eight years, before a dual language model is adopted (García \& Wei, 2014). In South Africa a subtractive bilingual education model where primary school learners are taught through their mother tongue for the first three years before English becomes the medium of instruction, is the norm (Heugh, 2015). Most teachers believe the best way for the learners to learn English is for it to be used exclusively within the classroom from Grade Four onwards (Creese, 2010). This belief means that many English teachers in South Africa believe that code switching, or switching between two languages on the part of the teacher, or the learners, minimises the learners' opportunity to practise their English (Creese, 2010). As a result code switching is not often endorsed by the school policies, and many teachers feel guilty or embarrassed when they code switch (Creese, 2010).

During the course teachers learned that translating part, or all of what was said from English into another language helps them to communicate more effectively with learners who are more proficient in their mother tongue than in English. However, if learners speak home languages that other learners, or the teacher, are not familiar with then they cannot benefit from code switching within the classroom. Code switching as a pedagogic technique also fails to recognise that bilingual children are fundamentally different from monolingual children as they use their language systems interchangeably (García, 2009). Instead of 
requiring learners to use languages as separate entities, translanguaging enables learners and teachers to use a mix of languages or language varieties (García, 2009). Thus, children can receive input in one or more languages, and provide output in a different language, or in a mixture of languages and language varieties (García, 2009). In this way teachers, even those who do not speak all the languages of their learners, can teach by using every single one of their learners' language practices (García \& Wei, 2014).

Translanguaging also allows learners to draw on non-standard forms of the languages they speak. In South Africa, teachers consider the most common variety of English, Black South African English to be inferior to Standard English because its structure is based on noncognate Bantu and Sotho-Tswana language (Van der Walt \& Van Rooy, 2002). Articles presented to the students argued that 1) Black South African English is a legitimate English variety that has developed over time and become more accepted as a norm within the country, and 2) Students could be taught how to use and adapt BSAE to approximate Standard English (Makalela, 2004; Makalela, 2013). In a context like South Africa where learners are plurilingual, they learn the target language more quickly and with a greater deal of fluency if they are allowed to translanguage.

While this course presented students with theoretical knowledge on bilingual education models and multilingual practices, current research suggests that most in-service teachers require an improved theoretical framework and practical grounding in order to teach plurilingual students (Breton-Carbonneau, Cleghorn, Evans \& Pesco 2012; Cajklera \& Hall, 2012). Despite research on bilingual education models and multilingual practices worldwide, there is limited literature within South Africa on how in-service AELS courses influence teacher praxis. This research aims to investigate teachers' perceptions of how an in-service course that focused on bilingual models and multilingual practices affected their praxis. In order to fulfil this aim the following research questions were developed:

Main research question:

How has an AELS course altered teachers' perceptions of their praxis?

Sub questions:

1. To what extent has this course made teachers more aware of their assumptions about teaching?

2. To what extent has this course made teachers more aware of context-based teaching?

3. To what extent has this course made teachers willing to alter any of their current practices?

While this research is important for language teachers working in schools it is particularly relevant for teacher educators who present alternative models of language teaching during inservice courses. This article discusses the evolution of praxis in light of the findings that teacher praxis is limited by a teacher' level of capital, parents and colleagues' views of bilingual models and multilingual practices, and 'English only policies' in schools. This article provides two suggestions regarding course content that would help graduate teachers to apply the knowledge from this course in practice. 


\section{LITERATURE REVIEW}

Praxis has a long history in the literature; Aristotle views praxis as informed moral action (Smith, Edwards-Grove \& Kemmis, 2010). Praxis can therefore be thought of as the space where theory and practice combine to form 'history-making action', or actions that produce different kinds of societies (Smith, Edwards-Grove \& Kemmis, 2010: 5). Thus, praxis is informed action designed to produce positive change in society. Teachers who use the theoretical knowledge gained in an AELS course to promote bilingual education models and multilingual practices to reduce inequalities in schools would be engaging in praxis.

It can be argued that without critical self-reflection teachers will not be able to engage in praxis. This is why in-service courses seek to develop reflective teachers who can transfer their learning to new environments (McKeough, Lupart \& Marini, 1995). While many inservice education courses ask teachers to reflect, for example through weekly reflection pieces, teachers are usually not explicitly taught how to show evidence of reflection in their writing (Blackburn, 2000). Without explicit instruction on reflection it is harder for teachers to create praxis by evaluating how suitable the theory that they have learned from in-service courses is to their context, and how effectively they have implemented this theory in practice.

While most teachers are not provided with guidance on how to critically reflect during inservice courses, Jay and Johnson (2002) have developed a typology with three levels of reflection, where the first level is the most simplistic, and the third is the most closely related to praxis (Marcosa, Sancheza \& Tillemab, 2011). The first level, descriptive reflection, occurs when students describe teaching and learning problems in the current school and wider educational context (Jay and Johnson, 2002). Students engage with the second level, comparative reflection, in order to consider the conflicting viewpoints that stakeholders such as parents, teachers and learners hold (Jay and Johnson, 2002). The third level, critical reflection, occurs when students use theory and observation to illuminate educational problems and unmask assumptions about the nature of schooling and the best way to teach increasingly diverse learners (Jay and Johnson, 2002; Reckwitz, 2002; Gay \& Kirkland, 2003).

According to Freire, reflection is the tool that enables people to name the conditions that create inequality (Blackburn, 2000). In Freirean education helping others become aware of any external realities that act as sources of oppression is a process called 'conscientisation' (Blackburn, 2000; Fuchs, 2003). Reflection to raise awareness of oppressive structures operating in one's life is pointless without action to change or operate more productively within these structures (Blackburn, 2000). Thus, once the conditions that create inequality have been named, people have the opportunity to become agents of change who can take action, no matter how small, to reduce these inequalities (Blackburn, 2000; Janks, 2000).

Reflection on the social context into which we are born may also allow in-service teachers to consider how they have developed three kinds of power referred to as economic, social and cultural capital. Economic capital refers to financial resources which are either very mobile, such as currency, or fairly fixed like property or shares (Bourdieu, 1986). Social capital refers to the networks that people can leverage in their favour through historic privilege, such as a title, or through group membership (Bourdieu, 1986). Cultural capital is either embodied as long-lasting dispositions, which are sometimes referred to as tastes and mannerisms, or made visible through objects, such as books or instruments and educational qualifications 
(Bourdieu, 1986). All forms of capital require effort and time to accrue, and economic capital can be used to gain social and cultural capital, for example through the purchase of a country club membership or the payment of university fees (Bourdieu, 1986). However, some learners are born to parents who have already acquired or inherited substantial levels of capital and have an advantage over those who have been born to parents with less capital (Bourdieu, 1986).

Those who have acquired cultural and social capital within a certain structure have a vested interest in maintaining the status quo. In the schooling context, older teachers who have accrued social capital through their networks, and cultural capital through degrees conferred based on prior syllabi are more likely to use 'conservation strategies' that maintain their capital within the school (Cveticanin, 2012: 38). In contrast, younger teachers with less capital are more likely to use 'subversion strategies' to introduce new practices, which if adopted would assist these teachers to increase their capital (Cveticanin, 2012: 38). Thus, age and experience seem to make teachers more risk averse and less likely to change their praxis.

\section{RESEARCH DESIGN}

A case study was used to provide rich qualitative data on in-service teachers' perceptions of their praxis regarding bilingual education models and multilingual practices after an AELS course. This was an exploratory case study as not much is known about this topic (Baxter \& Jack, 2008). As with any case study understanding participants' experiences in context was more important than obtaining generalisable data.

\section{PARTICIPANTS}

Eleven Honours and Master's students attended the AELS class. In light of the author's familiarity with the small group purposive sampling was used to select three Honours students who are or were language teachers working with learners in under-resourced schools or colleges (Baxter \& Jack, 2008). Participant A works at a high school that was designated for black children under Apartheid, and which is located in a former township area. Participant B studies full time; she formerly taught at a mission school in a peri-urban area. Participant $\mathrm{C}$ works at an FET college that caters for mainly black learners from township and rural areas who have failed their matric previously. In order to add to the richness of the data I have interviewed the course coordinator to get his opinion on the purpose of the course. Although the sample was small, the findings present an in-depth view of teachers' perceptions of their praxis after an AELS course. In terms of representativeness it is better to compare the experiences of three participants with similar experiences than to compare participants with very disparate experiences.

\section{DATA SOURCES AND DATA COLLECTION}

As part of the course participants were asked to write weekly reflection pieces. Due to the teachers' workload, participant A handed in six reflection pieces and participant B handed in five reflection pieces while participant $\mathrm{C}$ could not locate her reflection pieces. In order to increase the validity of the interview questions 5-7 potential probing questions were generated per each sub-question. Participants were then invited to take part in an audiorecorded interview, which lasted between 35 and 45 minutes. 


\section{DATA ANALYSIS METHOD}

Data was analysed using the 'ATLAS.ti' programme. The data from both the reflection pieces and the interviews were analysed using thematic analysis. Firstly, the reflection pieces were analysed thematically by searching for examples of descriptive, comparative and critical reflection as described in Jay and Johnson's (2002) typology (see Table 1).

Table 1: Typology of reflection: dimensions and guiding questions

\begin{tabular}{|c|c|c|}
\hline Dimension & Definition & Typical questions \\
\hline Descriptive & $\begin{array}{l}\text { Describe the } \\
\text { matter for } \\
\text { reflection }\end{array}$ & $\begin{array}{l}\text { What is happening? Is this working, and for whom? } \\
\text { For whom is it not working? How do I know? How } \\
\text { am I feeling? What am I pleased and/or concerned } \\
\text { about? What do I not understand? Does this relate to } \\
\text { any of my stated goals, and to what extent are they } \\
\text { being met? }\end{array}$ \\
\hline Comparative & $\begin{array}{l}\text { Reframe the } \\
\text { reflection in light } \\
\text { of alternative } \\
\text { views, others' } \\
\text { perspectives, } \\
\text { research, etc. }\end{array}$ & $\begin{array}{l}\text { What are alternative views of what is happening? } \\
\text { How do other people who are directly or indirectly } \\
\text { involved describe and explain what is happening? } \\
\text { What does the research contribute to an understanding } \\
\text { of this matter? How can I improve what's not } \\
\text { working? If there is a goal, what are some other ways } \\
\text { of accomplishing it? How do other people accomplish } \\
\text { this goal? For each perspective and alternative, who is } \\
\text { served and who is not? }\end{array}$ \\
\hline Critical & $\begin{array}{l}\text { Having } \\
\text { considered the } \\
\text { implications of } \\
\text { the matter, } \\
\text { establish a } \\
\text { renewed } \\
\text { perspective. }\end{array}$ & $\begin{array}{l}\text { What are the implications of the matter when viewed } \\
\text { from these alternative perspectives? Given these } \\
\text { various alternatives, their implications, and my own } \\
\text { morals and ethics, which is best for this particular } \\
\text { matter? What is the deeper meaning of what is } \\
\text { happening, in terms of public democratic purposes of } \\
\text { schooling? What does this matter reveal about moral } \\
\text { and political dimensions of schooling? How does this } \\
\text { reflective process inform and renew my perspective? }\end{array}$ \\
\hline
\end{tabular}

Source: Jay and Johnson 2002, p.77

Jay and Johnson's (2002) article made distinguishing between these types of reflection explicit by using a student's vignettes to illustrate which kinds of reflection were in use. Secondly, the interview texts were analysed using Bruan and Clarke's (2006) five step method of thematic analysis: 1) familiarising yourself with your data, 2) generating initial codes, 3) searching for sub-themes and themes, 4) reviewing sub-themes and themes, and 5) defining and naming themes. Once both themes and sub-themes emerged a 'thematic network' representing the relationship between themes and sub-themes was produced (Attride-Stirling, 2001). This analysis was data-driven as prior examples of relevant themes in the literature were absent. 


\section{ETHICS}

Ethical approval for this study was obtained beforehand from the Ethics Committee of the university. The participants were given a letter of informed consent to read before taking part in the study, and pseudonyms are used in this article to protect their identity. In order to minimise the risks of misunderstandings and misrepresentations the participants had the opportunity to review the data. No requests were made by the participants for retractions or additions to the data.

\section{RESULTS AND DISCUSSION}

\section{Types of reflection in participants' reflection pieces}

Participant A and B used descriptive reflection to outline how the course had highlighted current problems with language teaching; and comparative reflection to compare their knowledge before and after the course. Participant A used critical reflection (the reflection that most closely relates to praxis) to relate the knowledge gained within her specific school context to the wider educational context in South Africa.

Participant B's reflections like those of many teachers, provided descriptive accounts of theory or classroom practice, and did not show evidence of critical reflection (Marcosa, Sancheza \& Tillemab, 2011). In order for participant B to critically reflect she might have needed greater guidance on reflective writing (Marcosa, Sancheza \& Tillemab, 2011). It is also possible that she was unable to relate her teaching experiences from Zimbabwe to the articles used during the course, which described research from South Africa, America, Canada and Europe (McKeough, Lupart \& Marini, 1995).

A key to the schema for the themes and subthemes which emerged from the interviews and reflection pieces is found in Figure 1.

Figure 1: Themes emerging from the data

\section{Themes emerging from}

the data

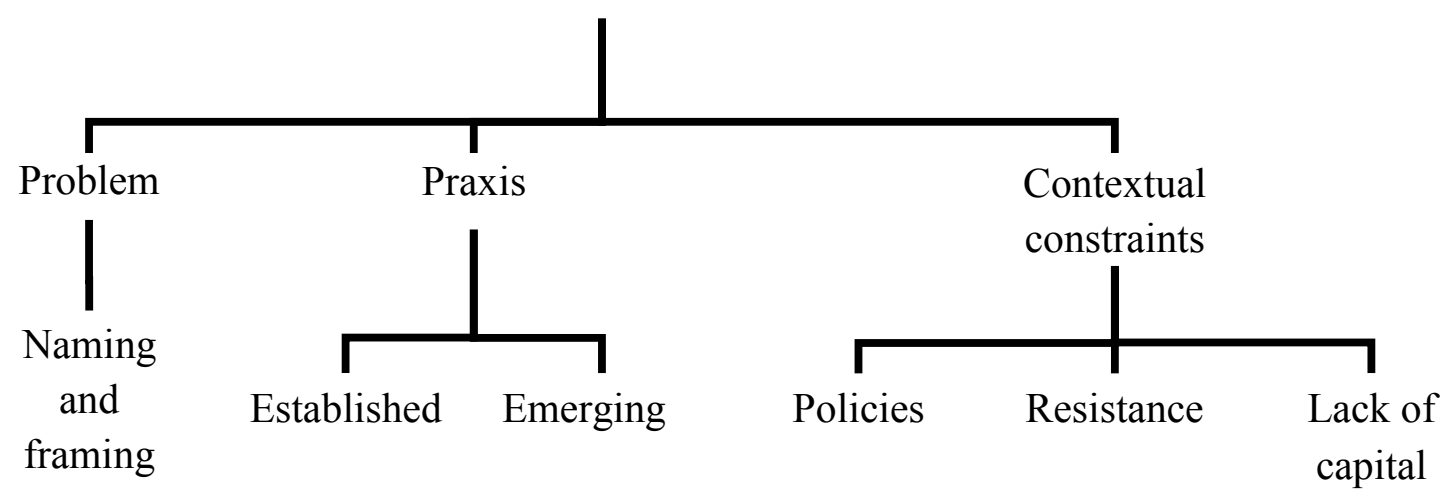




\section{Naming and framing the problem}

It can be argued that this course helped students achieve 'conscientisation' by giving them the ability to 'name and frame' issues around language teaching (see Figure 1), and understand how these issues were contextually situated (Blackburn, 2000). All participants said they were now more aware of how to teach in a bilingual context and commented that the course 'widens your view of language'. They now framed language and language teaching through a lens that included the terms translanguaging and BSAE.

After the course participant A considered language from a socio-cultural view; she said she understood that language is socially constructed, and that those with more capital, in this sense those with more knowledge of English than others, can empower themselves or control others more easily (Blackburn, 2000; Reckwitz, 2002).

Participants were also able to describe how the course's arguments for multilingual educational practices contrasted with their previous experiences,

'... especially in township schools, you in the English classroom you're not allowed to speak any other languages you must only speak English, and I think most of the teachers that are there have been to township schools, and they grew up thinking like that as well. So when you were taught like that you tend to teach like that as well' (C).

\section{Established and emerging praxis}

During the reflection pieces participants seemed willing to put all the new ideas presented in the course into practice. However, in the interviews it emerged that there was a tension between established and emerging praxis. Participant A said that she had believed past research that indicated that code switching would confuse the children in class. Her feelings of guilt around the use of code switching when learners did not seem to understand the lesson mirrors the findings of other researchers (Creese, 2010; King \& Chetty, 2014). After the course participant A realised that code switching had a sound pedagogic basis, and she said that she felt 'empowered' to use translanguaging in class. For her mini-research project she found that learners who used translanguaging in the classroom had answered the questions more clearly than those who used English only. Hence, participant A had redesigned part of the curricula by using more accessible multilingual education practices instead of the dominant monolingual practices (Janks, 2000). Due to the changes in practice she felt that she was in the process of 'Becoming a $21^{\text {st }}$ century language teacher'.

Participant $\mathrm{C}$ thought learners from former model $\mathrm{C}$ schools, designated for white learners under Apartheid, in Gauteng tended to speak more in class and that translanguaging could help learners from township schools participate. Despite this she had reservations about translanguaging,

'I'd have to know their languages for me to be able to use it. If I don't then it's a problem, because they can always go on and on about something that's not part of the discussion and when I ask they say 'Oh, we're just talking about nouns.' 
Resistance to this practice for a similar reason, i.e. the worry that it will cause a teacher to lose control of the class while the learners discuss things in other languages, was given by teachers in a previous study (Hooijer \& Fourie, 2009).

Participant $\mathrm{C}$ was also concerned that translanguaging would only benefit learners if teachers in the succeeding year at the FET College would use it in class,

'....then if I do it now say maybe I do it in a year with them and then they pass that level they go to the next level with a different teacher who doesn't do it at all then they can't participate at all because they're so used to translanguaging in the previous level, and now all of a sudden they are not allowed to do it they don't know how to..umm, stick to English alone anymore.'

Unlike participants A and C, participant B had not accepted that translanguaging allowed learners to harness all of their linguistic potential. Instead she argued for a particular model of code switching, where teachers give input in the learners' home language and receive learners' output in the target language; she argued that this would make it easier to assess the learners' English.

When participant $\mathrm{C}$ noticed learners from former model $\mathrm{C}$ schools teasing those from the township schools who spoke BSAE she talked to them about how BSAE is an accepted norm in South African society. In fact all participants emphasised the importance of teacher 'flexibility' with regard to spoken English '... we are no longer sticking to the norm, because of globalisation, and we are somehow speaking into the way we feel comfortable with' (B).

During the one-on-one interviews the participants' acceptance of spoken BSAE did not extend to written BSAE; participant A and B were concerned with 'upholding standards'. They believed that written BSAE had an inferior grammar to that of 'Standard English'. This is in line with Van der Walt and Van Rooy's (2002) research which shows that 69 per cent of teachers in South Africa thought that BSAE grammar diverged too strongly from that of Standard English. Participant $\mathrm{C}$ was more accepting of written BSAE, but was concerned that by accepting written BSAE she would disadvantage her learners,

'...So I can make the students aware...you know what you're not entirely wrong, but it is of your advantage to use it this way, because somebody else who's going to be marking this, they'll see this as a mistake. Though I can be accepting of it, the next person might not be, so if they go to the teacher the following year, they start failing [then the learners will say] 'we've been using it like this.'

Participant $\mathrm{C}$ feels that since both the external examiners and the other teachers at the FET College do not mark according to BSAE she should rather continue to teach her learners to reproduce 'Standard English'.

\section{Contextual constraints}

There were three kinds of contextual constraints operating on participant teachers: 1) school policies which support transitional bilingualism, 2) resistance towards bilingual education practices from parents and teachers, and 3) learners or teachers' lack of capital (see Figure 1). 
This fits with Bourdieu's argument (1977) that praxis cannot be an emancipatory force separated from context (Reckwitz, 2002).

In terms of the school policies both participant A and B had said that their current and former school administration tried to enforce an English only policy. Participant B also said that the policy in the English department of the school she had taught in emphasised British English over other Englishes.

Both participant $\mathrm{A}$ and $\mathrm{B}$ reported instances of resistance towards bilingual models and practices on the part of parents and teachers who thought that using only English would benefit the learners. This result is probable given that under Apartheid bilingual education for black children was generally of a sub-standard level and designed to limit learners' ability to master the English language (Heugh, 2015).

Participant $\mathrm{C}$ mentioned that older teachers were more resistant to change,

'She, she's gonna come in and explain it, what it is, give examples, and then expect the students to know, then try and put nouns into context, try and make that lesson more interesting for the students, no, I've been doing it like this for 10 years.'

This finding makes sense when one considers previous research which indicates that older teachers try to preserve a status quo that maintains the social and cultural capital that they have accrued over time (Cveticanin, 2012). The student also reported that older male teachers in the English department, were allowed to voice their ideas more freely, which is not surprising when one considers that gender and age would traditionally have afforded them greater capital.

While participant B felt that learners would also resist attempts at bilingual education participant A's experience had shown that the learners had enjoyed the translanguaging experience and felt that it helped them understand the task at hand. In terms of capital, participant A reported that learners said, 'it would be fair if we were allowed to speak in our languages, even in Science if the teacher could explain to us we would grasp the concepts better', they added that they felt uncomfortable to challenge the views of those with more power than them, 'but then it's not allowed so who are we?' This comment speaks to learners' feeling that they are not in a position to question the authority of adults in positions of power in the school setting.

All of the participants were able to name the structures that impeded their emerging praxis, namely: unfavourable school policies, resistance towards bilingual education from parents and teachers, and learners or teachers' lack of capital, but none of the participants was able to suggest strategies for overcoming these structures.

\section{RECOMMENDATIONS}

While it can be argued that the aim of this course is to teach students theory, not change their praxis, by its very nature a course on paradigms and methods in Applied English Language Studies should prompt teachers to re-examine their praxis. This is especially true in a country 
that largely does not cater for bilingual or plurilingual learners, many of whom speak English as a foreign language.

In order to help students re-examine their praxis more critically attention could be devoted to fostering students' ability to write written reflection pieces. As participant $C$ could not locate her reflection pieces her ability to reflect could not be assessed. However, participant B's written reflection did not display evidence of critical reflection while participant A's reflection pieces discussed how the theory from the course could be or had been implemented in her classroom. Although the course coordinator argued that teaching students to reflect in a certain manner would be too prescriptive, greater guidance on how to critically reflect during the course may enable students to reflect more critically on how to use the theories and ideas present in the course within the classroom, particularly as the course coordinator's feedback to the class indicated that their reflection pieces were too descriptive and needed to be more critical. Critical reflection could be fostered through the use of a broad typology, for example Jay and Johnson (2002) used their typology of reflection to deepen the written reflections of their Teacher Education Master's students.

This course gave students the ability to name current bilingual models and practices. Articles describing how teachers managed to implement bilingual educational models and practices in similar contexts could also help students understand and potentially overcome the resistance to bilingual education on the part of parents and other teachers. Only once the sources of these resistances are understood could the teachers in this AELS course overcome external resistance to certain ideas, such as the acceptance of BSAE and translanguaging. Although this course focuses on language teaching in South Africa, students could be referred to sources from their own countries as additional reading material. If students were taught to reflect on both theoretical articles and articles where the theory regarding bilingual models and practices has been implemented it would be easier for them to create praxis within their classrooms.

Thus, students may find it easier to transform their praxis if they are given readings which show how teachers implement bilingual models and practices in their classroom, and if they are shown how to display evidence of reflection in their writing (Jay \& Johnson, 2002). As these techniques have been used by academics in tertiary environments previously, fears that these methods necessitate prescriptive teaching are unfounded; AELS lecturers and course coordinators can ensure that academic standards remain high by implementing these suggestions in a manner which promotes critical engagement with students.

\section{LIMITATIONS}

As the cost of translators was prohibitive the interviews were conducted in English. Future research in similar fields with a bilingual or plurilingual researcher could have provided additional perspectives. I was unable to observe the teachers and they may have said that they adopted certain practices that they had not. Many of the participants were present in the research methods course where I discussed the aims of my study, and may have tried to provide me with answers they thought I required. Despite these concerns I found that participants who knew more about my study were less anxious during the interviews. Furthermore, both participants who attended the research methodology course, and the one who did not attend appeared honest in the interviews. For example, they strongly disagreed with evidence for the use of written forms of BSAE in the classroom. Other researchers could 
measure the effect of similar courses on teacher praxis by observing the teachers in the classroom.

The participants were all female Honours students who were teaching or had taught in under resourced schools or colleges. Although it was easier to compare the experiences of participants with similar experiences, further research is needed to determine how teachers from different backgrounds with different experiences perceive their praxis after completing an AELS course.

\section{CONCLUSION}

The AELS course required graduate teachers to consider changing paradigms for how bilingual learners are viewed in society and consequently how they should be taught. This is important because teachers of English, through the way that they teach, can enhance or restrict access to a language which has amassed a significant amount of symbolic and functional power. The findings from this study are very encouraging as they show that all three of the teachers have adopted a more linguistically inclusive teaching praxis. For example, all the teachers said that they had become more tolerant of spoken BSAE and code switching. However, there was reluctance to accept written BSAE due to fears of failure to uphold 'Standard English' and only one participant had embraced translanguaging. The course could be modified by guiding students on how to reflect critically in written form and providing students with literature on the implementation of the theory in context. These two suggestions could promote teacher reflection and help teachers implement the theory from this course in practice.

\section{REFERENCES}

AKBULUT, Y. 2007. Bilingual acquisition and cognitive development in early childhood: challenges to the research paradigm. Elementary Education Online, 6(3):422-492.

ATTRIDE-STIRLING, J. 2001. Thematic networks: an analytic tool for qualitative research. Qualitative Research, 1(3):385-405.

BAXTER, P \& S JACK. 2008. Qualitative case study methodology: Study design and implementation for novice researchers. The Qualitative Report, 13(4):544-559.

BIALYSTOK, E \& R BARAC. 2012. Emerging bilingualism: Dissociating advantages for metalinguistic awareness and executive control. Cognition, 122(1):67-73.

BLACKBURN, J. 2000. Understanding Paulo Freire: Reflections on the origins, concepts, and possible pitfalls of his educational approach. Oxford University Press and Community Development Journal, 35(1):3-15.

BOURDIEU, P. 1977. Méditations pascaliennes. Paris: Seuil.

BOURDIEU, P. 1986. The forms of capital. In Richardson, J (Ed). The Handbook of theory and research for the sociology of education. New York: Greenwood. 46-58.

BRETON-CARBONNEAU, G, A CLEGHORN, R EVANS \& D PESCO. 2012.

Pedagogical and political encounters in linguistically and culturally diverse primary classrooms: Examples from Quebec, Canada, and Gauteng, South Africa. Compare: A Journal of Comparative and International Education, 42(3): 373-391. 
BRUAN, V \& V CLARKE. 2006. Using thematic analysis in Psychology. Qualitative Research in Psychology, 3(2):77-101.

CAJKLERA W \& B HALL. 2012. Multilingual primary classrooms: An investigation of first year teachers' learning and responsive teaching. European Journal of Teacher Education, 35(2):212-228.

CREESE, A. 2010. Translanguaging in the Bilingual Classroom: A Pedagogy for Learning and Teaching? The Modern Language Journal, 94 (10):103-115.

CVETICANIN, P. 2012. Bourdieu's Theory of Practice. In Cveticanin, P (Ed), Social and Cultural Capital in Serbia. Serbia: Centre for Empirical Cultural Studies of SouthEast Europe. 25-52.

FUCHS, C. 2003. Some implications of Pierre Bourdieu's works for a theory of social selforganization. European Journal of Social Theory, 6(4):387-408.

GAY GG \& K KIRKLAND. 2003. Developing cultural critical consciousness and selfreflection in preservice teacher education. Theory Into Practice, 42(3):181-18.

GARCÍA, O. 2009. Bilingual Education in the 21st century: A global perspective. Oxford: Wiley Blackwell.

GARCÍA, O \& L WEI. 2014. Translanguaging: Language, Bilingualism and Education. Hampshire: Palgrave Macmillian.

HEUGH, K. 2015. South Africa: Three periods of bilingual of multilingual education. In Mehisto, P \& F Genesee (Eds). Building Bilingual Education Systems: Forces, Mechanisms and Counterweights. Cambridge: Cambridge University Press. 243-263.

HOOIJER, E \& J FOURIE. 2009. Teacher's perspective of bilingual classrooms in a South African school. Education as Change, 13(1):135-151.

JANKS, H. 2000. Domination, Access, Diversity and Design: A synthesis for critical literacy education. Educational Review, 52(2):175-186.

JAY, JK \& KL JOHNSON. 2002. Capturing complexity: A typology of reflective practice for teacher education. Teaching and Teacher Education, 18:73-85.

KING, RJ \& R CHETTY. 2014. Codeswitching: Linguistic and literacy understanding of teaching dilemmas in multilingual classrooms. Linguistics and Education, 25:40-50.

MAKALELA, L. 2004. Differential error types in second-language students' written and spoken texts implications for instruction in writing. Written Communication, 21(4): 368-385.

MAKALELA, L. 2013. Black South African English on the radio. World Englishes, 32(1): 93-107.

MCKEOUGH, A, J LUPART \& A MARINI. 1995. Teaching for transfer: Fostering generalization in learning. New Jersey: Lawrence Erlbaum Associates Inc.

MARCOSA, JM, E SANCHEZA \& HH TILLEMAB. 2011. Promoting teacher reflection: what is said to be done. Journal of Education for Teaching: International research and Pedagogy, 37(1):21-36.

RECKWITZ, A. 2002. Toward a theory of social practices a development in cultural theorizing. European Journal of Social Theory, 5(2):245-256.

SAYED, Y \& C SOUDIEN. 2005. Decentralisation and the construction of inclusion education policy in South Africa. Compare: A Journal of Comparative and International Education, 35(2):115-125.

SMITH, T, C EDWARDS-GROVE \& RB KEMMIS. 2010. Pedagogy, education and praxis. Pedagogy, Culture \& Society, 18(1):1-8.

VAN DER WALT, JL \& B VAN ROOY. 2002. Towards a norm in South African Englishes. World Englishes, 21(1):113-128. 


\section{BIOGRAPHICAL NOTE}

Laura Arnold works at University of Johannesburg's Postgraduate Centre as an Academic Facilitator. Her research interests include literacy development, particularly the acquisition of academic literacies at postgraduate level.

Email address: 1arnold@uj.ac.za 